\title{
This shoal which is not one: Island studies, performance studies, and Africans who fly
}

\author{
Rebecca Schneider \\ Brown University \\ Rebecca_Schneider@brown.edu
}

\begin{abstract}
This essay explores variant stories surrounding the 1803 'Igbo Landing' on St. Simons Island, Georgia, in which a group of enslaved Africans mutinied against their captors and ran aground upon a shoal. Following Tiffany Lethabo King and other scholars of Black feminist thought, the essay explores not only the littoral fact of shoals in seafaring but also the concept of shoaling for troubling historical narratives oriented to settler colonial plot points. Following island studies scholar Jonathan Pugh, the essay asks what thinking with performance and the concept of liminality might offer attempts to account for sand, drift, and, in this case, accounts of Africans who fly. The essay also tells a story of its own regarding the author's attempt to approach the historical site of Igbo Landing by sea. An example of performative writing, the essay does not so much launch and unpack a singular argument as it explores the littoral zones among and between ideas, stories, arguments, facts, and fabulations in relation.
\end{abstract}

Keywords: Africans, Georgia, islands, performance studies, relationality, shoals

https://doi.org/10.24043/isj.135 • Received February 2020, accepted October 2020

C 2020 - Institute of Island Studies, University of Prince Edward Island, Canada.

\section{Setting out}

Simultaneity is its proper aspect - a proper(ty) that is never fixed in the possible identity-to-self of some form or other. It is always fluid, without neglecting the characteristic of fluids that are difficult to idealize: those rubbings between two infinitely near neighbors.

—Luce Irigaray, This Sex Which is Not One (1985, p. 79, italics in original)

Plantation futures can go two ways at once: first where the basic system is left untouched and we are left to defend and justify it, and, second, where the awareness of the workings of the system are engendered in a (creative and geographic) plot-life, and, at the same time, challenge this logic. The latter future offered, I suggest, cannot withstand inevitable black-death because it asks that we imagine black-life as anticipatory. —Katherine McKittrick, "Plantation Futures" (2013, p. 11) 
In 1803, a group of enslaved Igbo-speaking African people who had survived the middle passage mutinied against their captors before running aground in the salt marshes at Dunbar Creek on St. Simons Island, Georgia. The slave ship that carried them from West Africa had probably come to port first on the mainland in Savannah where they were all auctioned for sale at the slave market before being shackled together on a smaller vessel, the schooner York, to be sailed to the island. Seventy-five in number, they had been purchased for $\$ 100$ a head by John Couper, a white Scotsman who had a plantation on the island at Cannon's Point, and Thomas Spaulding, a white man who had been born on St. Simons and was a planter with 350 slaves on neighboring Sapelo Island to the north. Both of those islands had, for thousands of years, been home to the Mocama and Guale native peoples, though by the time the vessel York heaved up in the brackish creek, many of the Indigenous who had survived infectious disease and warfare had either been enslaved or had evacuated, first to Florida and then to Cuba as the Spanish ceded the territory to the British. By 1803, when the York went aground, it went aground in America, and stories began to circulate about what had taken place. Were the Igbo 'recovered' and delivered to the plantations? Did they drown? Or, as some say, did they manage to escape entirely, even finding their way home?

Early $19^{\text {th }}$-Century St. Simons was in the throes of what some now term, after Donna Haraway and Anna Tsing, the 'Plantationocene'-a proposed alternative name for the geological epoch we now inhabit, more often called the Anthropocene (Mitman, 2019). The word Plantationocene, like Françoise Vergès's proposed 'Racial Capitalocene' after Cedric Robinson (Vergès, 2017), better underscores that the entangled environmental crises we face cannot be decoupled from histories of colonialism, capitalism, and racism that had parsed the general Anthropos into human and less-than-human under the white liberal auspices of 'Man'. If the word 'Anthropocene' puts blame generally on the human as species, that blame is misplaced. Our condition more truthfully stems from what Sylvia Wynter (2005, pp. 117119) has termed a "genre" of being human-Man and his "macro-discourse of liberal humanism." This is a genre, or "mode" of human, to cite Elizabeth Povinelli (2016, p. 16; see also Coulthard 2014, p. 33), that has, vampire-like, spread its colonial-capitalist lifeway of resource privatization and extraction for profit wherever it goes. Today on St. Simons Island, plantations have given way to sprawling private golf courses attended by luxury vacation condos, hotels, and marinas. Plantation buildings now serve tourism. A promotional video for John Couper's former plantation at Cannon's Point promises "ruins dating back to the 1800s." To the dulcet tones of romantic music, an invitation appears in text over a dilapidated tabby wall pockmarked with oyster shell and slowly dissolving to dust: "Remove yourself from the everyday" (Golden Isles CVB, 2020).

The irony in 'removal' is painful. Indeed, removing themselves from the everyday of American enslavement was surely the aim of the enslaved who mutinied aboard the York. Some of the people who survived the shoaling may have ultimately been delivered to Couper's or Spaulding's plantations to serve the semiophagic machine of slavery's capitalism (Beckert \& Rockman, 2018). Yet depending on the version of the story that finds you, none of them may ever have arrived at all. For, there are many ways to tell and retell the story of what happened in the wake of the York's island grounding, and those versions ascend from but also recompose a vibrant Black diasporic folklore of 'Africans who Fly' (McDaniel, 1990; Powell, 2010; Young, 2017; Hallock, 2019). 
In this essay, I will explore the variant stories of Igbo Landing in order to think about the undecidability at the base of the tale in relationship to what Tiffany Lethabo King (2019a) has termed "Black shoals." Along the way I will ask questions about liminality in assemblages of human with more-than-human (and more-than-human among themselves) and I will look to points at which island studies might generatively intersect with performance studies. Telling a story of a voyage of my own, and moving from St. Simons Island to Jeykll Island at the close, the essay will not conclude nor congeal into a singular point, like a singular island, but will (as if performing a shoal of its own) anticipate Africans who fly.

\section{What happened?}

Stories circulate in currents and drift, sometimes carried by mouth, sometimes ferried by paper or danced or sung in orature, passing limb to limb. Versions and allusions to versions of the Igbo Landing story appear in visual art, poems, novels, film and video-witness Julie Dash's film Daughters of the Dust or Beyonce's Love Drought in Lemonade. Depending on how it finds you, the story of flying Africans at Igbo Landing tells of life or death or, better said, life in and beyond death even while telling of enslavement's death in life. As versions of the story go, some things remain constant: the captives revolted, and two white crewmen and their white captain were either killed or jumped overboard and drowned. When the ship eventually fetched up on a shoal, the Africans onboard were still mostly chained together. They disembarked as best they could in irons. But here the versions begin to drift apart. Some say that together and singing "the water carried us here, the water will carry us away," they walked (back) into the creek. Some say they walked onto and over the water. And some say they reached out their arms, caught the wind, and flew away. In this version, rising up and over the island, they circled in the sky before heading east, riding air currents across the sea again to Africa. Some say they turned into buzzards.

This is a story of a great circular current, continent to continent, sea to air, sand to sky. The mutiny and shoaling of the York on a barrier island performs itself as a story at a fulcrum of inversion or return. Of course, another version of the ending holds that together, and "preferring death to captivity" (Parish, 1942, p. 37), the people in chains walked singing into the water to drown in a "freedom march" of collective suicide (Momodu, 2016, n.p.). The multiple versions of this story resound with still circulating cross-currents of pain and joy, an optimism and pessimism sounding in percussive iterations that do no resolve (or do not only resolve) (Colbert, 2017; Wilderson, 2010, p .39, pp. 58-59; Sexton, 2011; N'yongo, 2019, pp. 19-21). But perhaps either way and simultaneously_rising into the air to fly away and/or walking into the water to drown - the Igbo at Dunbar Creek refused the plot that the island plantations held in store. So in terms of the variant endings to the tale, perhaps both can be true-drowning and flying. Who is to say what happened? Who is to say that folk in the littoral zones among life and death do not fly? As Toni Morrison $(1977$, p. 337, italics in original) writes at the conclusion of Song of Solomon, itself a retelling of the 'Africans who fly' narrative, "If you surrendered to the air, you could ride it." And the poet Yona Harvey (2013, p. 34) recirculates the tale in the context of Katrina in a stanza of her poem Hurricane: 


\author{
Girl, you can ride \\ A hurricane \& she do \\ $\&$ she do \& she do \& she do
}

\begin{abstract}
At base, the choice to refuse to decide which ending is definitive (death or flight) refuses the over-determination of plantation plot, in part by refusing to produce the decided body of the (death of the) African (see Ronald Judy, ctd. in Wilderson, 2010, p. 39). The refusal to produce a decided body, like a decided narrative, may be an example of what Haitian sociologist Jean Casmir (2012, p. 183) has termed "counter-plantation" life. Casmir writes of Black radical agrarian traditions of maroon settlements of colonial and revolutionary SaintDomingue as "systems" that refuse capitalist logics. Counter-plantation lifeways may also be found among the Gullah-Geechee on the Georgia Sea Islands where, in part because of island isolation, the enslaved were able to resist the "full instrumentalization of their lives and labor" and produce "robust alternatives to the agribusiness model of the plantation" (Moore et al, 2019, n.p.). On Saint Simons and Sapelo, the Gullah-Geechee formed autonomous Black communities that persist, though precariously, to this day. Their stories are fascinating in relation to shifting, unstable assemblages of fact, fiction, and fabulation (Cooper, 2017). The story of Igbo Landing is most certainly theirs, even as it can be joined up with diasporic tales of flying Africans globally. Local and oceanic, the Igbo Landing story circulates broadly, carrying forth and returning to its island particulates.
\end{abstract}

\title{
Rival geographies and stories as shoals
}

In Closer to Freedom, Stephanie M. H. Camp (2004, p. 36) reads "everyday resistance" in $19^{\text {th }}$ Century counter-plantation life as taking place within the plantation system itself rather than counter to it if "counter" suggests a dialectical opposition. Perhaps the everyday resistance Camp discusses is rather like the "simultaneity" referred to in the McKittrick epitaph above: plantation life could be both itself and counter to itself. Reading plantations as "geographies of containment," Camp (2004, p. 36) reads everyday practices including the truancy of enslaved women who, often repeatedly for short or long periods of time, refused to stay "fixed" in plantation space. For Camp, swamps and woodlands were "rival geographies" where the fixity of plantation plot could, even if only momentarily, and even in conditions of abject uninhabitability, come undone in "loopholes of retreat" (Snorton, 2017, pp. 71-73). In this way of thinking, swamps, woods, salt marshes and their shoals all partake of something shared, perhaps, by the broader oceanic tidalectic of unfixity (Brathwaite, in DeLoughrey, 2007, pp. 1-48). At least in the imagination, or carried on the breath of a song, multiple rival geographies shift with living, co-present and irruptive aspirations, shoals-loopholes-for the storied potentials of 'flight'. Thus we might think of stories and song, too, as rival geographies. As such, they offer modalities of undecideability and invite the shoals to interrupt us again and again, not only in the shifting interstices of land and sea, but in the shifting interstices of time where the stories come to find us.

It is interesting to consider that stories, and most particularly their performance in/as orature - the passing of stories mouth to mouth and body to body—may form a kind of rival geography where the aspiration of non-fixity, or removal from the plot, is manifested in the many versions of a tale. The suggestion is that storytelling or fabulation may harbor a mode 
otherwise to plantation life or Plantationocenic plot, even if simultaneous to that plot. That stories circulate in multiple versions suggests a form of what Edouard Glissant called 'archipelagic thought': local and individual versions (no two are identical) that are simultaneously interconnected. As opposed to "systemic thought," for Glissant archipelagic thought is "intuitive, more fragile, threatened, but in sync with the chaos-world and the unforeseeable," archipelagic thought "attunes the written to the oral and the oral to the written" (Glissant \& Joris, 1999, pp. 119-120). The 'Africans who fly' narrative flies on the wings of a story that, as Soyika Diggs Colbert (2017, p. 27) relates, becomes a "source for imagining futures within the Black diaspora that are predicated on understandings of the human that exceed the physical instantiation of the body." Perhaps one way to think about this is to accede that a body is always more than itself, lifting off of itself through gesture, word, and intra-action (Schneider, 2018). Stories, borne on breath, pass beyond the singular body enunciating syllables into the air and articulate an "aesthetic of possibility" (Crawley, 2017, pp. 32-85). Can one be caught up on the shoal of another's story, arrested even if momentarily into an irruptive alternative to the steady-on course of capitalism's extraction machine? If so, is a story rather like shifting sand beneath our feet? Not precisely chartable, not singularly navigable, in place but not plottable, both shifting and nevertheless carrying an extreme granularity of locale?

In 'What the sands remember', a beautiful essay that concerns the ephemera of queer Caribbean lives, anthropologist Vanessa Agard-Jones (2019, p. 339) considers what becomes of sand from a Martiniquan beach that catches in the crevasses of queer couples' bodies who gather on the strand to make love. She asks what sand might offer as a "repository for queer memory." At the start of the essay, before bringing the reader to the beach with her, AgardJones compares words in a poem—-specifically syllables—-to grains of sand. Sand, that "object that exists at the point of nature's hesitation between land and sea" is an object that "smooths rough edges but also irritates, sticking to our bodies' folds and fissures" (Agard-Jones, 2019, p. 326). Each grain, syllable-like, carries a geologic specificity even as it catches in our hair, our mouths, our asses, and our toes. Sand moves with us to carry space across time. Sand as the stuff of shoals shifts while also carrying fine-grained details of place. So too do stories. Especially stories that, wayward, refuse geographies of containment and their Plantationocenic legacies to catch us up in fugitive particulates that refuse to be (only) fixed. Like shoals, such stories run against the grain of logic and stop us short. At the fulcrum of the tale, we catch our breath on queerness: they flew.

In The Black Shoals: Offshore Formations of Black and Native Studies, Tiffany Lethabo King (2019, p. 4) writes similarly of sand and the "liminal space between the sea and the land." Offering thinking with shoals as a way to exceed habits of metaphor that would delimit Blackness to the analytic of the liquid oceanic and Indigeneity to the analytic of static land, King (2019, p. 12) draws on Brathwaite's tidalectics and the littoral entanglement of sea and sand as a way to "confound the binary and dialectical thinking" in preference for attention to irruptive ephemera, shifting opacities and littoral relationality that can "connect Indigenous and Black diasporic thought reparatively." Not only are shoals profoundly liminal, but in an exciting passage, King (2019, pp. 12-13) almost suggests that shoals are 'living'. She writes that "Black studies in its Caribbean, Canadian, US, Brazilian, North American and Latin American iterations all shift and respond to one another (albeit unequally) like living shoals." Though the "living" in this sentence is metaphorical, it is not only metaphorical as King relates 
shoaling to the activity of gathering and conversing and enfleshing as the book unfolds. Ultimately, shoaling is a kind of making as "combining, merging, and creating new forms of Black embodiment - particularly errant Black bodily forms- [...] pushes at the limits of what is conventionally construed as the human body" (King, 2019, p. 117). The famous Spinozist claim that "we do not yet know what a body can do" suggests that flight, as well as running aground, can be a material particulate of not/yet/knowing (Spinoza, 1985, p. 495).

\section{Liminal / littoral}

Island studies scholar Jonathan Pugh (2016, p. 1042) similarly leans toward the liminal and the unstable, arguing that island studies is best approached as an assemblage of ocean, island, and ship. "Islands draw us towards the sense of a fixed object while at the same time remaining the product of multiple and unstable assemblages." Here Pugh (2016, p. 1042) draws on Deleuze and Guattari's notion of assemblage (informed by Spinoza) as a "continual de- and re-composition that is only ever partially stabilized." He asks that we resist thinking of boat, sea, and island as "discrete entities" but read them instead as "dynamic and shifting assemblages associated with affective intensities and convergences between human and more-than-human relations" (Pugh, 2016, p. 1044). To do this, and compellingly, Pugh turns to thinking with performance, specifically dance, through the Barbadian 'Landship' in which dancers embody ship relations and sea orientations through choreography, their bodies at sea and on land simultaneously. The Landship performance is decidedly local and specific to Barbados even as it shifts its temporal particularities over time from slave ship to steam ship to cruise ship, all "powerful capitalist relations that work through changing island, sea, and ship relations" (Pugh, 2016, p. 1055). To address the locality of the shifting sands of the local dance, if you will accept a sand/gesture correlation, at the end of his essay Pugh steers away from Deleuze and Guattari's deterritorialization toward Glissant's relationalilty. Pugh cites J. Michael Dash (qtd. in Pugh, 2016, p. 1054) who writes that “even at his most 'Deleluzean' Glissant does not yield to a radical poetics of deterritorialization but hangs on to the specifics (opacité, densité) of locale." Like the simultaneity of land and sea in Landship, the simultaneity of flight and drowning in the Igbo Landing tale is littoral, pronouncing a liminality that, fundamentally both/and, refuses to resolve or complete. Passage is, instead, suspended at the threshold. Rather than decide definitively what a body can do, preference is toward de- and recomposing its Relations.

Pugh's turn to dance performance is no mistake. King (2019, pp. 3-4), too, draws on performance studies at the very opening of The Black Shoals to theorize shoaling as occurring in a zone of shift - a zone, like performance, of "converging, gathering, reassembling and coming together (or apart)." In fact, performance has long been imagined as liminal. As theorized in 1982 by anthropologist Victor Turner, who situated liminality as an essential aspect of ritual, the liminal became something of a conceptual shoal upon which performance studies as an (anti)discipline founded and then dispersed itself. The liminal came to define an act or action that occupies a position "betwixt and between," such as between the state of youth and adulthood in rites of passage, or more broadly between the material and the immaterial, embodied yet ephemeral, disappearing yet reappearing. In early performance studies work, the theatre stage or any performance space was theorized as a liminal space-in which actions were not real but not not real, or in which the real could be suspended and 
liminality explored for aesthetic possibilities. Yet, liminality (and its seeming constitutive betweenness) has also been a point of debate within performance studies, specifically around the question of whether liminality implies a dialectical tension that necessarily drives toward resolution. Does liminality's opaqueness or unfixity merely serve as a passageway both from and to the dominant norm of either side in an opposition? Is it merely a zone of 'wandering' that inevitably returns to or otherwise serves an insular status quo? Performance studies scholars like Fred Moten (2008) and Sarah Jane Cervenak (2016) have carefully explored the ways liminality can thwart dialectical resolution when accessed in the "dialect" of the Black radical tradition which Moten (2008, p. 134), in 'Not in between', reads through C.L.R. James reading through Haiti.

Performance studies may share something with island studies if the shifting aqueous netherworld of sea and shore shares something with the movement into and out of materiality and immateriality that characterizes zones of performance. Dance, theatre, orature, and gestures that repeat are at once singular and citational, continually de- and re-composing. Considered in relation to the larger landmass of 'the real', theatrical or performance-based acts such as stories, dances, and plays are not real but not not real, just as Landship dancers are not at sea but not not at sea. In the netherworld of performance, solid states oscillate toward becoming undone, and fluid states syncopate with stasis. The so-called human, too, laps at its own borders as one so-called human plays at becoming another, speaks through another, or takes the shape of a spirit, a stone, a tree, a ship, a wave, a dream, a bird.

\section{Human more than human}

A story, such as the tale of Igbo Landing, may be the same story in multiple, different forms as it passes in rendition mouth to mouth, body to body, generation to generation, medium to medium. Such a story shifts, it irrupts, it recurs-and, composed in seriality like archipelagic thought, is never completely the same twice. As each enunciation is singular, and local, it is also caught in the relational flow that stories perform ( $\&$ she do $\&$ she do $\&$ she do). That the outcome or endpoint of the tale is undecideable may in itself manifest Colbert's (2017, p. 27) "source for imaginings."

The reader may have noticed that the opening epigraph of this essay recites French feminist scholar Luce Irigaray's This sex which is not one, in which Irigaray attempts to displace male-centered structures of language and habits of thought through a writing practice that might be called, especially in her later work, oceanic (Irigaray, 1982, 1991). Refusing the phallocentric delimitation of woman to 'sex' informs Irigaray's title on the one hand, but on the other, Irigaray's writing also suggests that women's sexuality is more than one-never only one-as in the littoral and erogenous zone of two lips together. Women, for Irigaray, are not delimitable to a category of mankind. In essence she asks that we attempt to account for women outside of or beyond the delimitation to the phallocentrism that would always revert to the self-sameness of liberal human Man. Though this essay is not about women per $s e$, it is about rival thinking, beyond the delimitation, the plots, of overdetermined fixed states. The suggestion here is that thinking with shoals, and liminality/littorality in general, may enable a capacity toward what we do not/yet/know. To be caught upon a shoal is to be arrested out of flow from within flow, but it is also a fulcrum point for the potentiality of otherwise ways of knowing (King, 2019b). 
Thus, in terms of thinking with the 'living shoals' of the Igbo Landing story's undecided outcome, it may be interesting to work to think outside the "narrativity of the liberal subject or human" (King 2019a, p. 21) and to take seriously the shifting particularity of the shoal in Dunbar Creek itself. Not land, not not land, not sea, not not sea, the assemblage of ocean, island, and ship at the moment of Igbo shoaling is, in Pugh's (2016, p. 1044) words, "human and more-than-human."

Here, however, an interesting problem arises in thinking about the York in the 'human and more-than-human' of Pugh's ocean, island, ship assemblage where Pugh aligns the ship with 'human'. Given the enslaved 'cargo' on the York, and the fact that the white human enslavers aboard the boat had perished, might we be invited to challenge the alignment of boat with human or only human? That is, when un-Manned by whites, or even before, did the 1803 assemblage ship and human shift? This is to take seriously the call by Frank Wilderson and other Afro-pessimists to resist the categorization of Black as necessarily completely incorporable into the genre 'human' without troubling that genre to its racist historical core. Recall that Wynter unpacked the 'human' as aligned to the animacy hierarchies of white liberal settler-colonial humanism, and she troubled this genre as fundamentally anti-Black. However, if thinking of the enslaved aboard the York as 'nonhuman' simply replicates the very plantation logic upon which the enslaved at St. Simons foundered or flew, we might instead adopt Monique Allewaert's liminal term 'para-human'a term she actually reads for its promise against dehumanization by coding it as 'interstitial':

[The] parahuman body that is guided, or governed, as though it were an animal body is in analogical relation to the animals and to the human beings to which it is proximate. Under the logic of colonialism, this analogical relation worked to produce a hierarchy of species whereby the African slave was conceived as an interstitial form of life that could be exploited for labor power in the way animals were and that also protected Anglo-Europeans from recognizing their own animality. In taking up the term parahuman, I aim to challenge the hierarchical organization of life-forms that was common on colonial anthropologies and natural histories: I put animals, parahumans and humans in horizontal relations (that is to say para or beside each other) without conflating them. (Allewaert, 2013, pp. 85-86)

Allewaert goes on to explore the strategies of resistance that developed through the performances of those designated as parahuman and finds models of personhood that "registered a deep skepticism about the desirability of the category of human." As she argues, "Parahumans built modes of self and politics that were not simply critiques of the category of the human but suspended it so as to prohibit any simple return to it" (Allewaert, 2013, p. 87).

The parahuman, in Allewaert's analysis, is interstitial, composed as a syncopation of human and more than human. Rather than wholly jettison the Plantationocenic logic that haunts parahumanity, Allewaert asks that we consider the spaces that are opened by the more than human as rival geographies of possibility. Not Man but not not Man is a liminal assemblage. Man and what else? As performance scholars have long enjoined, the power of the doubled negative (that an actor is not Hamlet but not not Hamlet) pronounces an aesthetic of possibility that in its very oscillation is infinite and not limited to simple betweenness but always leaning toward the surplus, the what else-ness, of performance (Schechner, 1985, p. 
110; Moten, 2008; King, 2019b). Parahuman is simultaneously human and more than human, refusing to congeal into Man, remaking human in the erotic registers among becoming (Jackson, 2020) and unbecoming (King, 2019b, p. 48). With this in mind, we might return to Pugh (2016, p. 1044) and his important request that we resist thinking of boat, sea, and island as "discrete entities" but read them instead as convergences of relations between "human and more-than-human." What happens when Pugh's assemblage becomes morethan-human (the ship), more-than-human (the sea), more-than-human (the land), and morethan-human (the human)? When we add to the assemblage the multiple genres of human in play, what changes in our accounts of what a body, what a ship, and what (else) the land can do or could have done or may yet do? At the very least, it seems to me, we might be invited to think of (Black) shoaling and the stories it fetches up as both borne on breath, passing body to body, and assemblages of more-than-human possibilities - elsewise to the (white) mode of Man that insists upon inevitable resolution to insular geographies of containment, privatization, and extraction. Indeed, in writing of the way shoals are relentlessly littoral and thus impede our too easy arrival at any mooring, any stasis, any resolution, any conclusion, King draws on Katherine McKittrick's investment in noticing "what else." King calls the littoral zone of "what else" the "surplus of Black livingness- that exceeds black death, black suffering, and the black body" (King, 2019b, p. 48).

\section{This shoal which is not one}

At this point in the essay, I make a turn to tell another story of shoaling. My own. This is a story that runs alongside, perhaps, without overtaking but also without ever arriving at the story of Africans who fly.

In January of 2019, I set off on a journey to approach Igbo Landing and other sites of the Georgia Sea Islands by water. I wanted to go there, and I wanted to travel by water, if only to try and think with the water along the way. The story of Igbo Landing is not my story, except to the degree that the story of chattel slavery implicates all of us who live in the wake not only of Indigenous removal and Black enslavement but in the wake of the disproportionate white wealth thereby generated. None of us, especially not whites like myself who are descended from settler-colonials, are able to simply wash our hands and say, "That is not a story of $m y$ people." What happened to the enslaved who drowned and/or flew, happened to them because they were caught up in a 'drama' (a word used repeatedly by slave ship historian Marcus Rediker as well as by Saidya Hartman in Scenes of Subjection), staged by many players on many islands and continents in a cross hatch of "routes and roots" in slavery's capitalism (DeLoughrey, 2007). Taking a sabbatical leave, I wondered whether thinking about the oceanic and the tidalectics of history might be affected by thinking aboard a boat? If the "sea is history," as Derek Walcott (2007, p. 137) wrote, I wondered what kind of access to its archive might be granted by a seafaring vessel.

Aboard the sailing vessel Artemis, a pleasure yacht of 38 feet with a 4.5 -foot draft and a 12 -foot beam, I was in some ways as far as one can get from chattel slavery. As a white American my relationship to what Christina Sharpe (2016) has termed "the wake" of the transatlantic slave trade is fundamentally different from those whose ancestors were forced across the sea as captives, and yet the currents of capitalism empowered by the forced labor of slaves are part of the ongoing afterlife of slavery that impacts all Americans even as, or 


\section{Rebecca Schneider}

particularly as, we are differentially positioned in relationship to the wealth engendered by the "accumulation and fungibility" of slave labor (Wilderson, 2010, p. 14). Being aboard a pleasure yacht is not being aboard a slave ship, and yet historically there are many examples of pleasure yachts turned slavers - such as the yacht Wanderer that ran aground on Jekyll island, just south of St. Simons, in 1859.

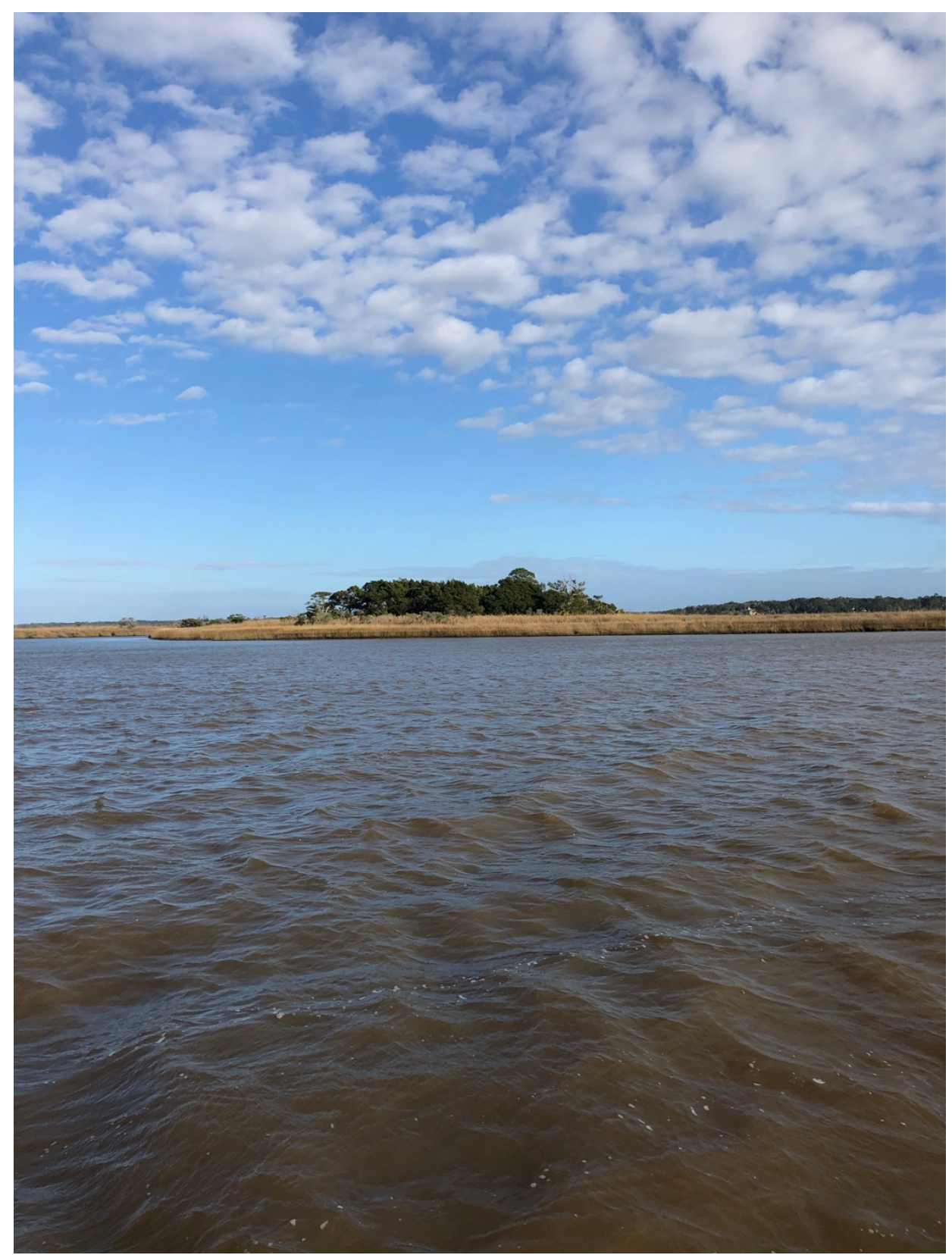

Figure 1. A view toward St. Simons Island from the Artemis in the middle of the McKay River separating St. Simons Island from the mainland. Source: (C) Rebecca Schneider 


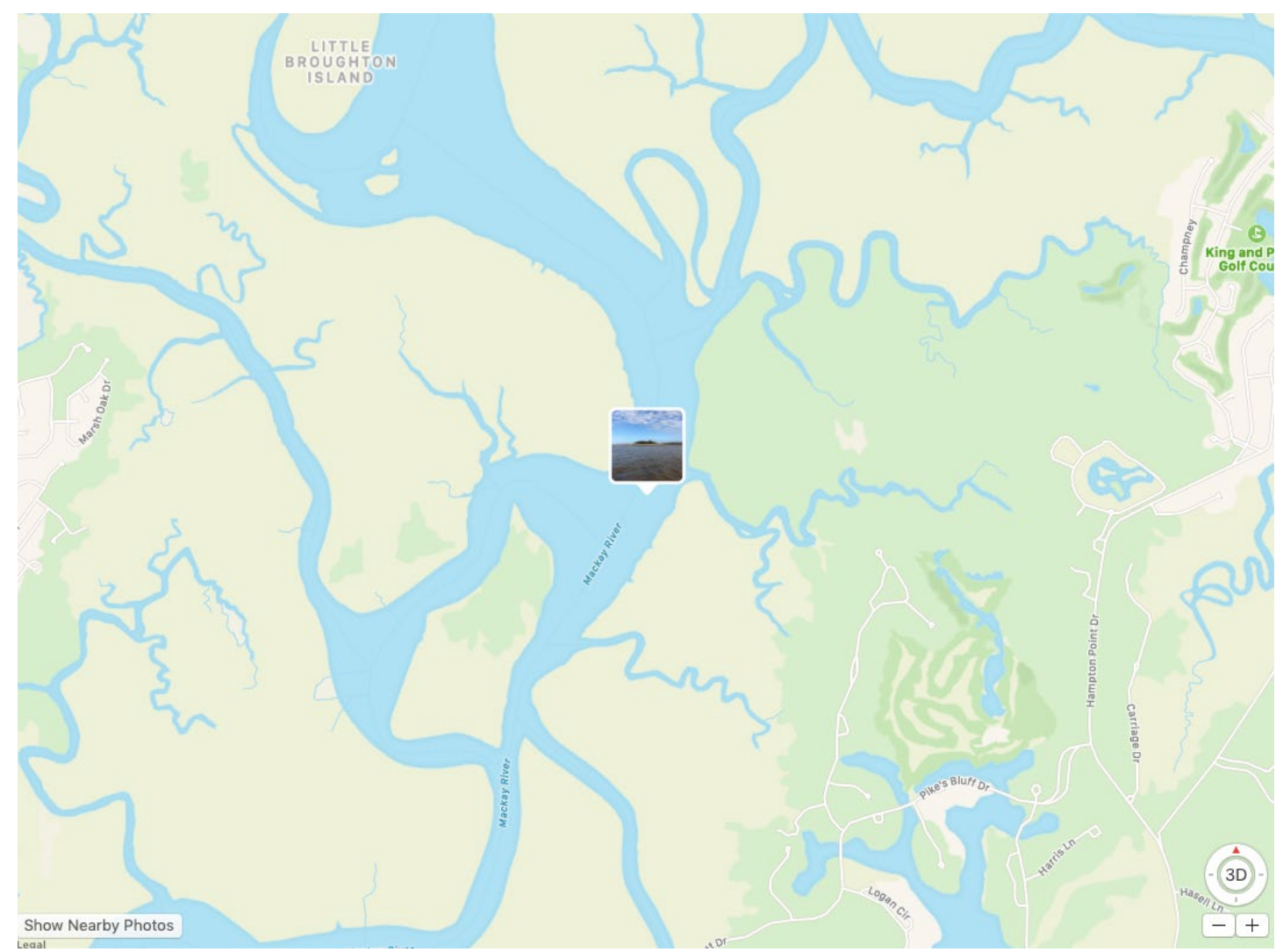

Figure 2. A chart showing an aerial view of where the photograph in Figure 1 was taken. Source: (C) Rebecca Schneider.

I was sailing with my husband Will who makes his living as a sea captain. We were not, therefore, completely daft, at least in terms of seaworthiness. As we sailed down the MacKay River, looking for Dunbar Creek, he knew that we would never get as close to it by means of our own vessel as I might have imagined when we set out from Rhode Island four weeks prior. Dunbar Creek is not navigable by a vessel such as ours, even with our shallow draft. Then again, it was not navigable by the mutinied York in 1803 either. To add to the difficulties, depths are not charted reliably for the creek. In fact, 'Ebo Landing' only appeared on one of the nautical charts we searched. On all charts, Dunbar Creek appears as a snaking riverway winding its way through salt marsh to join the Frederica River, which itself snakes forth to join the MacKay and the sea. Still, what would it be like to come close? How close is 2019 to 1803 ? How close is close while staying safely away from the shallows that would ground us? How close is far away? After a daylong sail in the murky, windy January waters that separate the outer islands from the continent, past Ossabaw and Sapelo, we found ourselves alongside St. Simons. Determining that we would get nowhere near Dunbar Creek that day, we turned to port in St. Simon's sound to steer a course toward a marina. At the fulcrum of the turn, however, and well away from any marker, the Artemis fetched up on a shoal invisible to the naked eye and not anticipated, in time, by our older depth finder which only notes a shoal directly underneath the hull. That is, our equipment could not anticipate shoals in advance, even if that is precisely what we were doing by chasing history as if it snaked in front of us like wetlands never at rest.

So, we were not there. And yet there we were. Caught on a shoal between the island and the mainland, between the island and itself, in the crevasses that disaggregate the island 
from the continent and the open sea. We were not aboard a slaver. We were not enslaved. We were not descended from enslaved peoples. We were not even close. And yet there we were. We had been asking something of the ocean, of history, and of time. But who did we think we were? Fetched up there, going nowhere-where were we? How could we possibly know anything - of the ocean, of the island, of the slave ship, of history in the snaking byways of nonlinear time on the tide? Stalled as we were betwixt and between, among the many currents of sand, water, and history, the shoal had brought us literally to a grinding halt. It may not have been 'our' shoal to shoal upon, and yet, there we were, not there.

This is a story, then, of not arriving. Stories that are not (only) ours nevertheless come to find us and sing a song of implication in the broader sets of Relations we shoal upon in our efforts to navigate the past. As a tourist, and the descendent of settler-colonial enslavers, can the 'black shoal' stop me short and turn my question, like a tide, upon myself and my forbears and their lifeways: What happened? The details are not undecideable. Some of my ancestors in Georgia and elsewhere had participated in the enslavement of Africans and the removal of Indigenous peoples, but even if those particulars were not true of me (and they are), the sand of slavery sticks to the pores of all of us awash in the capitalist circum-Altantic and grinds the particulates of history against our skin - as our skin. What is undecideable are not the facts of what happened, but our response-ability to and with the sand that shifts our Relations in time. What will we do in the spaces opened among or shoaled upon the morethan-human to alter the course, or founder the ship, of white liberal humanism in the ravages of the Plantationocene it continues to plot?

These were not coherent thoughts at the moment of shoaling in St. Simons Sound. Our immediate concerns were for safe dislodging from the shoal where we were brought to a halt a half a mile from shore. All attention turned to getting off the shoal. We had scraped our hull before, but only once or twice to no significant account on rocky outcroppings in the intercoastal waterway. Some passages are named for the treachery of their shallows, such as Hell's Gate, north of Ossabaw Island at Racoon Key. We had navigated Hell's Gate passage successfully in part because of the hypervigilance by which mariners hail its active bottom, orating conditions on a daily or even hourly basis to each other across the airwaves or on digital nav sites. Timing with the tide is basic seamanship, but word of mouth captain to captain is key as well. But it's more often the innocuous, unnamed, and sudden shoals that seem to reach out to nudge you, or tap you on the shoulder as if to remind you that you are in the nether regions of land and sea, among the salt marshes where visibility is challenging, in the undecided and shifting places among shorelines. More often than not it is a sudden, shrugging surprise of land as if ship and rock and sand and water were all animate beings jostling along the same course, with equal rights of passage, each competing for room to move along, move along. The number of our near misses with these beings was impossible to count as we watched our depth finder register shoal after shoal beneath us underway. Uncharted and unchartable shoals irrupt, unmarked, with a logic of their own determined opacity and had reminded us a couple of times that not only are waterways not fixed, but even the most expert vigilance will not keep the drift entirely at bay. And in any case, this is as it should be- not only with the movement of water and land, but with the movement of history and narrative as well.

As we turned to port in St. Simon's sound and came upon the shoal, we were fortunate to find that the shoal was sand. We were only held in place for a matter of minutes, maybe 
five, maybe ten, maybe twelve. Time did not register in its usual flow. And though the rising tide would not have kept us there long in any case, still the amount of time we were stranded seemed vast. In the short time that we heaved up, almost gently, upon the bar, we experienced a kind of suspension, a moment of undecideability, regarding our potential to be anything other than at the mercy of the amalgam.

Moments before the shoaling, I had been preparing the boat for docking. I was bent down on the starboard side, opening the lifeline in order to tie on the fenders (to avoid damaging the hull on a dock). So I was at a point of extreme precarity when the boat pitched and lurched to a stop. I was thrown down and had to grab the gunwale to keep from falling overboard. Will was busy trying to spin us around, using the engine (we were motor-sailing, having dropped the main), but in fact there was little we could do. We had to wait for the shoal to let us go again. Which it did. But not before that peculiar experience of being grounded mid-water, in our case still quite far from shore, generated the sudden sensation of interruption, arrest, and fear that took the immediate shape of disbelief.

Afterwards, we were silent as we headed up the sound toward a marina. The irony of shoaling en route to Igbo Landing (where we never arrived) was not lost on either of us, though what to make of it would never become clear. Perhaps we never arrived because it simply could not be ours to know. We would not get there by sea in any case- the goal was faulty from the start. The next day, renting a car, we called the Coastal Georgia Historical Society located on St. Simons to find out where and when we might visit Igbo Landing by land. Surely there was a memorial there, a park, or a marker at the very least. But the woman on the phone told me she had "never heard of it." As white folk (as this Historical Society clearly were), Igbo Landing may not be "ours to know," but is it really OK to have never heard of it? I was astounded, which was clearly legible in my voice and probably also a function of my whiteness. Picking up on my concern, the woman promised to look into it and call me back with information. No one from the Coastal Georgia Historical Society located on St. Simons ever called me back.

As I likely should have done from the start, I immediately called the St. Simons AfricanAmerican Heritage Coalition. Not only had they "heard of it," but they were happy to help. The coalition was founded in 2000 out of concern about the encroachment by development in the historical African-American neighborhoods on the island. On their website they state:

SSAAHC is made up of African-American property owners and concerned citizens alike who care about preserving the African-American land, heritage, and culture on St. Simons, recognizing that St. Simons was built on the backs of the AfricanAmerican community. As St. Simons continues to grow, pressures from increased land speculation have caused African-American families to sell out and move off the ancestral lands where they have resided for the last 150 years. Sites and structures precious to the history and memory of the community are being torn down and built over. Bit by bit, the African-American heritage on St. Simons is being erased and African-American islanders are leaving the very community their ancestors made possible (SSAAHC, 2019, n.p.).

Through the Heritage Coalition, I was connected with a Gullah-Geechee guide named Amy Roberts, the executive director of the coalition, and given a tour not only of Igbo Landing 
but significant sites for African-American heritage on the island as a whole, including the birthplace of Jim Brown, hall of fame football player.

Amy Roberts told us the story of Igbo Landing as we drove to a private backyard that backs onto Dunbar Creek. Because it is 'private property', Ms. Roberts is the only guide granted access to the land abutting the creek that is recognized by the Heritage Coalition as the historical site of the shoaling. There is no plaque, no marker, no sign. There is only someone's backyard. But as she has written in Gullah-Geechee Heritage in the Golden Islands, "No one really knows exactly which property it is" (Roberts \& Holladay, 2019, p. 53). She regularly takes interested visitors there on Tuesdays, driving them in her car from the Harrington Schoolhouse, down Atlantic Avenue, and off Frederica Road. As long as you are with 'Miss Amy', you can walk onto the backyard and down to the creek. When we pulled up in the yard and got out to stand by the creek, Amy Roberts stayed in the car. I asked later if she thought the Africans flew that day (a piece of the story she had not offered in the version of the story she told to us). She said simply, "Some say so."

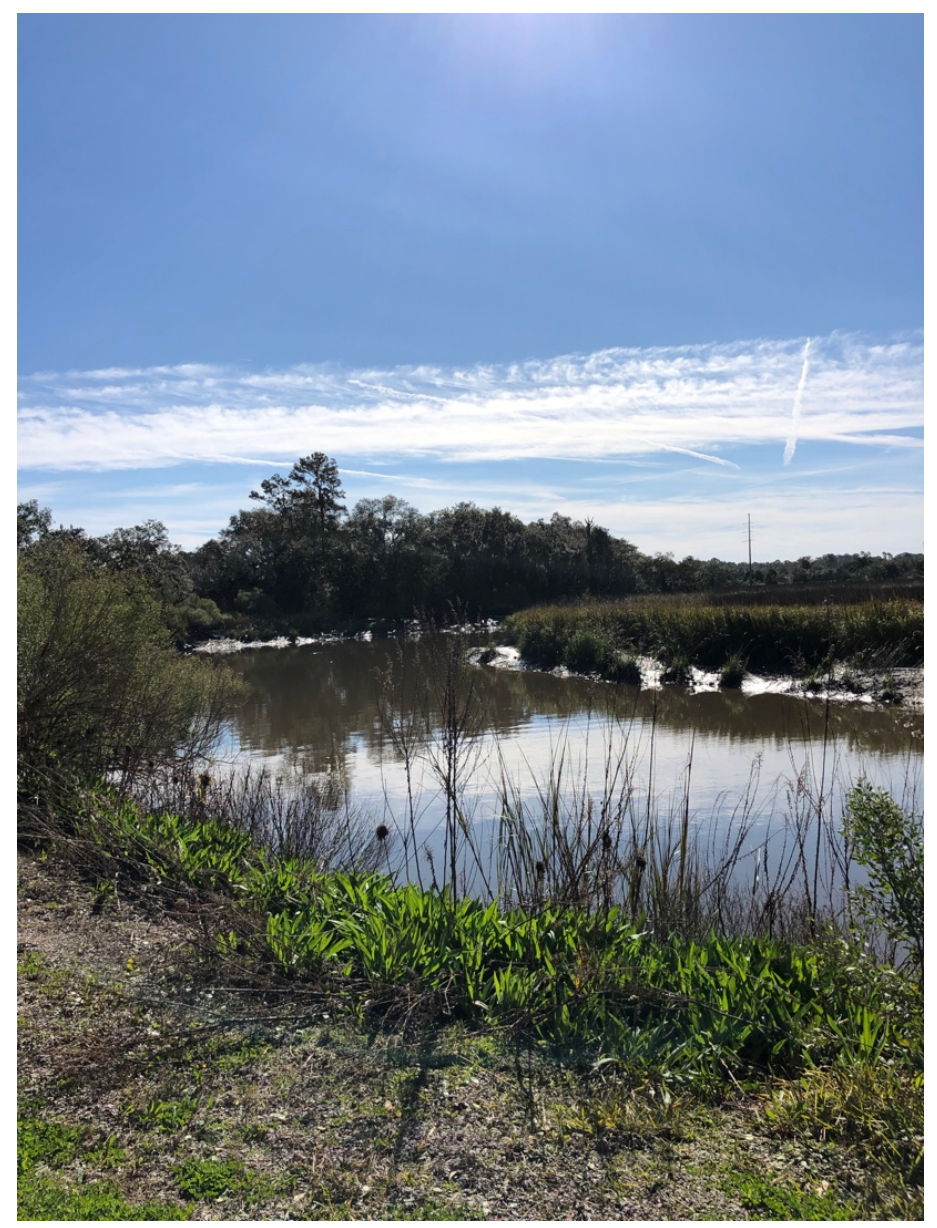

Figure 3. Dunbar Creek, Igbo Landing. Source: (C) Rebecca Schneider.

\section{A conclusion which is not one}

If white and non-black scholars can bare or expose the ways that their white/nonblack self depends on rendering the black body a captive "being for" whiteness/others, it is possible to render themselves available for being radically 
rearranged by Blackness. This work leaves room for the formation of a new kind of body - a Deleuzean Body Without Organs - that can be undone and remade in relation to blackness. This kind of ethic and reorientation can interrupt the current impulse to objectify black embodiment and black life while transforming the white and non-black scholars who hope to abolish anti-black violence in their own work. —Tiffany Lethabo King, 'Off Littorality (Shoal 1.0): Black Study Off the Shores of "The Black Body"' (2019b, p. 48)

Perhaps there is not much of a 'story' in my effort to sail to Igbo Landing. My own tale does not congeal to a fulcrum or even come to a point, even as it fetches on a shoal in a sound. Rather my efforts are like a set of snaking, intersecting byways meandering through a salt marsh, headed simultaneously toward and away from the history I sought. Sure, Igbo Landing was on Dunbar Creek. But more certainly it was in the breath of the story as that air lifts up and away from those who retell it. Sure, it lifts up and away, but often by way of return-turn to the creek, turn to the tale, turn to the question not only of what happened but what else? What route to take from a there that is not there and not not there simultaneously?

After St. Simons, we sailed the Artemis on to Jekyll Island to the south. There, an exhibition in a nature park, funded in part by the Smithsonian, commemorates the illegal arrival of the pleasure yacht turned slaver named the Wanderer. In 1859, the Wanderer arrived at Jekyll after 42 days at sea during which 80 of 487 captives onboard had perished. In the waters off Jekyll, the captain rowed a dinghy to neighboring Cumberland Island to the south, looking for someone who could pilot the Wanderer over Jekyll's notorious sandbar. A pilot was found, the ship was anchored, and the enslaved were offloaded to be hidden in the Jekyll woods. Some were smuggled to Savannah for sale, but the plot was found out, the Wanderer impounded, and the smugglers were put on trial before being, wealthy plantation owners among them, all acquitted in 1860. The Wanderer was put to work for the Union Army before foundering on a shoal off Cuba in 1871.

On Jekyll, the Wanderer memorial takes place along a beachside walkway. Stations along the path each recall an aspect of the slave trade in general and the Wanderer in particular. One large sign lists as many of the Wanderer's captives as can be accounted for by name. Then, at the end of the walkway is a speaker on a stand with a sign that reads 'Flying Back'. Press a button and a version of the story of the Africans who flew at Igbo Landing is released into the air. As I listened, it struck me as interesting that the Igbo Landing story is told on Jekyll, the island beside St. Simons. But if we were rising above Dunbar Creek, getting high enough on the wind, Jekyll would be the first rest we might take on a long flight south. The undulating shoals where islands come together could remind us of a story carried on the air. If the sea is history, as Walcott says, then it is history that flows between St. Simons and Jekyll, and among and around us all.

I then noticed that just beyond the 'Flying Back' speaker station stands a 'Wildlife Viewing Platform'. The platform is not part of the commemorative walkway itself, as far as I could tell. This platform affords a broad view of the beach and waterway but no explicit relationship is drawn between it and the sailing vessel Wanderer or the memorial walkway it abuts. A sign simply tells a would-be climber that the platform is meant to enable an "experience of wildlife on Jekyll." 


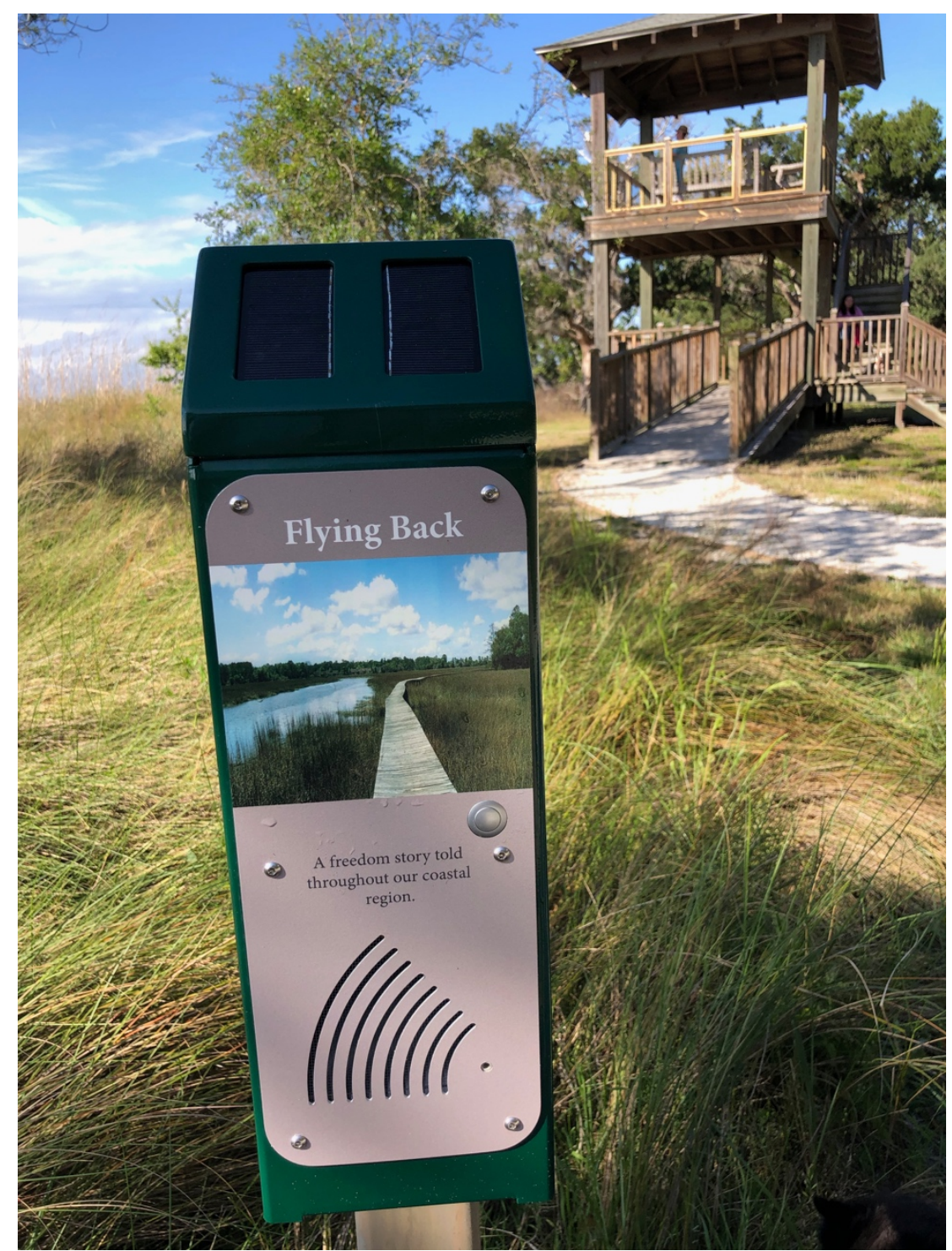

Figure 4. Wanderer memorial. Source: (C) Rebecca Schneider.

I climb. The view takes the eye out beyond the beach to the sea and the sky where the wildlife on view is either the breaching or the flying kind. I recall, then, being lifted by the shoal and I think that I might just try, as King invites, to leave room for the formation of a new kind of body.

\section{References}

Agard-Jones, V. (2012). What the sands remember. GLQ: Gay and Lesbian Quarterly, 18(23), 325-346. https://doi.org/10.1215/10642684-1472917

Allewaert, M. (2013). Ariel's ecology: Plantations, personhood and colonialism in the American tropics. University of Minnesota Press. https://doi.org/10.5749/minnesota/9780816677276.001.0001

Beckert, S., \& S. Rockman. (Eds.) (2018). Slavery's capitalism: A new history of American economic development. University of Pennsylvania Press.

https://doi.org/10.9783/9780812293098-001 
Beyoncé.

(2016).

Love

drought.

Lemonade.

https://www.youtube.com/watch?v=CUyQSKe75L4

Camp, S.M.H. (2004). Closer to freedom: Enslaved women and everyday resistance in the plantation south. University of North Carolina Press.

Casmir, J., \& M. Claypool. (2012). Going backwards toward the future: from Haiti to SaintDomingue. The Global South, 6(1), 172-192. https://doi.org/10.2979/globalsouth.6.1.172

Colbert, S.D. (2017. Black movements: Performance and cultural politics. Rutgers University Press.

Cooper, M.L. (2017). Making Gullah: A history of Sapelo Islanders, race, and the American imagination. University of North Carolina Press. https://doi.org/10.5149/northcarolina/9781469632681.001.0001

Coulthard, G.S. (2014). Red skin, white masks: Rejecting the colonial politics of recognition. University of Minnesota Press. https://doi.org/10.3138/utq.86.3.230

Crawley, A.T. (2017. Blackpentascostal breath: The aesthetics of possibility. Fordham University Press.

Dash, J. (Dir.) (1991). Daughters of the dust. WMG Film.

DeLoughery, E. (2007). Routes and roots: Navigating Caribbean and Pacific Island literatures. University of Hawaii Press.

Glissant, E., \& Joris, P. (1999). From introduction to a poetics of the diverse. Boundary 2, 26(1), 119-121.

Golden Isles CVB. (2020). Cannon's Point Preserve. Golden Isles Georgia. https://www.goldenisles.com/listing/cannons-point-preserve/373/

Hallock, T. (2018). Space, time, and purpose in early American texts: Starting from Igbo landing. Early American Literature, 54(1), 21-36. https://doi.org/10.1353/eal.2019.0004

Harvey, Y. (2003). Hemming the water. Four Way Books.

Irigaray, L. (1985). This sex which is not one. C. Porter (Trans.). Cornell University Press.

Irigaray, L. (1991). Marine lover of Friedrich Nietzsche. G. Gill (Trans.). Columbia University Press.

Jackson, Z.I. (2020). Becoming human: Matter and meaning in an antiblack world. New York University Press.

King, T.L. (2019a). The Black shoals: Offshore formations of Black and Native studies. Duke University Press. https://doi.org/10.1515/9781478005681

King, T.L. (2019b). Off littorality (shoal 1.0): Black study off the shores of 'the Black body'. Propter Nos, 3, 40-50.

McDaniel, L. (1990). The flying Africans: Extent and strength of the myth in the Americas. New West Indian Guide/Nieuwe West-Indische Gids, 64(1/2), 28-40. https://doi.org/10.1163/13822373-90002024

McKittrick, K. (2013. Plantation futures. Small Axe, 17(3),1-15.

Mitman, G. (2019, June 18). Reflections on the Plantationocene: A conversation with Donna Haraway and Anna Tsing. Edge Effects. https://edgeeffects.net/haraway-tsingplantationocene/

Momodu, S. (2016, October 25). Igbo Landing mass suicide (1803). Blackpast. https://www.blackpast.org/african-american-history/events-african-americanhistory/igbo-landing-mass-suicide-1803/

Moore, S.S., Allewaert, M., Gómez, P.F., \& Mitman, G. (2019, January 22). Plantation 
legacies. Edge Effects. https://edgeeffects.net/plantation-legacies-plantationocene/ Morrison, T. (1977). Song of Solomon. Vintage.

Moten. F. (2008). Not in between: lyric painting, visual history, and the postcolonial future. TDR, 47(1), 127-148. https://doi.org/10.1162/105420403321250053

Nyongo, T. (2010). Afro-fabulations: The queer drama of Black life. New York University Press. Parrish, L. (1942). Slave songs of the Georgia Sea Islands. Creative Age Press.

Povinelli, E.A. (2016). Geontologies: A requiem to late liberalism. Duke University Press.

Powell, T.B. (2010). Summoning the ancestors: The flying Africans' story and its enduring legacy. In P. Morgan (Ed.). African American life in the Georgia lowcountry (pp. 253-79). University of Georgia Press.

Pugh, J. (2016). The relational turn in island geographies: Bringing together island, sea, and ship relations and the case of the landship. Social and Cultural Geography, 17(8), 10401059. https://doi.org/10.1080/14649365.2016.1147064

Roberts, A.L., \& Holiday, P. (2019). Gullah-Geechee heritage in the Golden Isles. The History Press.

Schechner, R. (1985). Between theatre and anthropology. University of Chicago Press.

Schneider, R. (2018). That the past may yet have another future: Gesture in the times of hands up. Theatre Journal, 70(3), 285-306. https://doi.org/10.1353/tj.2018.0056

Sexton, J. (2011). The social life of social death: On Afro-pessimism and Black optimism. In Tensions, 5(Fall/Winter), 1-47.

Sharpe, C. (2016). In the wake: On blackness and being. Duke University Press.

Snorton, C.R. (2019). Black on both sides: A racial history of trans identity. University of Minnesota Press.

Spinoza, B. (1985). The collected works of Spinoza, volume 1. E. Curley (Trans.). Princeton University Press.

SSAAHC (2017). Educating, preserving, and revitalizing African American heritage and culture. Saint Simons African American Heritage Coalition. https://ssiheritagecoalition.org/

Turner, V. (1982). From ritual to theatre: the human seriousness of play. PAJ Publications.

Vergès, F. (2017). Racial capitalocene: Is the anthropocene racial? In G.T. Johnson \& A. Lubin (Eds.). Futures of Black radicalism. Verso.

Walcott, D. (2007). The sea is history. In E. Baugh (Ed.). Selected poems (pp. 137-139). Farrar, Straus \& Giroux.

Wilderson, F.B. III. (2010). Red, white, and Black: Cinema and the structure of U.S. antagonisms. Duke University Press. https://doi.org/10.1215/9780822391715

Wynter, S. (2005). On how we mistook the map for the territory, and reimprisoned ourselves in our unbearable wrongness of being, of desêtre. In L.R. Gordon \& J.A. Gordon (Eds.). Not only the master's tools: African American studies in theory and practice (pp. 107169). Routledge. https://doi.org/10.1002/9780470996645.ch9

Young, J.R. (2017). All god's children had wings: The flying African in history, literature, and lore. Journal of Africana Religions, 5(1), 50-70. https://doi.org/10.5325/jafrireli.5.1.0050 